\title{
Decomposition Process and Post Mortem Changes: Review
}

(Proses Pereputan dan Perubahan Pasca Kematian: Ulasan)

\author{
Teo Chee Hau, Noor Hazfalinda Hamzah, Hing Hiang Lian \& SRi Pawita Albakri Amir HamzaH*
}

\section{ABSTRACT}

Decomposition is degradation process of a corpse into basic respective constituents macroscopically and microscopically by action of microorganisms, arthropods and scavengers. Post mortem changes could be separated into early post mortem changes (i.e. algor mortis, rigor mortis and livor mortis) and putrefaction stages of corpse. These changes function as suitable indicators for determination of post mortem interval (PMI). In this paper, different stages of post mortem changes, possible variations such as mummification and formation of adipocere and special circumstances such as burial condition is discussed. This article also refers to several arguments in the different texture of adipocere and the influence of different types of fabric in affecting the post mortem changes and formation of adipocere. This is largely due to the property of permeability and resistance of material against degradation process. Undeniably, decomposition process involves numerous potential variables including burial condition, presence of clothing, potential formation of adipocere and mummification. Hence, studies in forensic taphonomy combined with real case scenario are crucial in understanding the nature of decomposition and estimation of PMI with higher accuracy.

Keywords: Adipocere; burial condition; decomposition; mummification; post mortem changes; putrefaction

\section{ABSTRAK}

Pereputan adalah proses penguraian mayat kepada bahan asas secara makroskopik dan mikroskopik melalui aktiviti mikroorganisma, atropod dan pembangkai. Perubahan pasca kematian dapat dibahagikan kepada perubahan pasca kematian awal (iaitu algor mortis, rigor mortis dan livor mortis) dan tahap pembusukan mayat. Perubahan ini berfungsi sebagai petunjuk yang sesuai bagi penentuan selang masa pasca kematian. Dalam ulasan ini, tahap perubahan pasca kematian yang berbeza, variasi seperti mumifikasi dan pembentukan adipocere serta situasi tertentu iaitu keadaan pengebumian telah dibincangkan. Artikel ini juga merangkumi beberapa pendapat yang bertentangan terhadap perbezaan antara tekstur adipocere yang terbentuk serta pengaruh faktor jenis pakaian yang berbeza dalam mempengaruhi perubahan pasca kematian dan pembentukan adipocere. Ini adalah disebabkan oleh tahap ketelusan dan ketahanan bahan terhadap proses pereputan. Tidak dapat dinafikan, proses pereputan melibatkan pelbagai faktor yang berpotensi, termasuklah keadaan pengebumian, pakaian, pembentukan adipocere dan mumifikasi. Maka, kajian dalam forensik tafonomi bersama dengan senario kes sebenar adalah penting untuk memahami proses pereputan dan penentuan selang masa pasca kematian dengan kejituan yang lebih tinggi.

Kata kunci: Adipocere; keadaan pengebumian; mumifikasi; pembusukan; pereputan; perubahan pasca kematian

\section{INTRODUCTION}

Decomposition is a natural process that occurs for every organism that has died. Initially, the degradation may not be visible to the naked eye as the process starts at the cellular level. Slowly the changes will progress to macroscopic and form the post mortem changes. This process continues even beyond the dry remains stage as the bones still undergo decomposition although at a much slower rate as previously seen. In the end, the whole decomposition process allows the recycling of energy flow and nutrient into the surrounding ecosystem (Fenoglio et al. 2010; Tibbett \& Carter 2009).

The understanding of post mortem changes is crucial for estimation of post mortem interval (PMI). PMI is the interval of time that has passed since the deceased passed away until the corpse was found (Parsons 2009; Poloz \&
O'day 2009). Generally, the longer the time of death has occurred, the less accurate the PMI estimate would be. Once the corpse has reached the dry remains stage, the estimation of PMI could be difficult due to influence of various environmental factors (Dautartas 2009; Kaliszan et al. 2009). Estimation of PMI is very important in crime investigations, event reconstructions and solving cases because an accurate time of death can help the courtroom in accepting or denying statements and alibi of suspects and witnesses. There are many ways in determining PMI for victims. Madea (2005) categorized the methods of PMI estimation into quantitative or subjective in nature and whether there is presence of independent variables or only based on assumptions.

It is undeniable that breaking down of tissue bulk to their building blocks takes time and the duration largely 
depends on intrinsic and extrinsic factors. Intrinsic factors include age and physical size of corpse, ante mortem medical condition and presence of trauma. Extrinsic factors on the other hand, include variation in surrounding temperature, weather, burial, clothing, presence of arthropods and scavengers. The progress of decomposition could be measured or quantified by a series of methods. These include carcass mass loss, carbon dioxide-carbon evolution, ninhydrin-reactive nitrogen, microbial biomass carbon and faunal succession pattern, etc (Carter et al. 2008a; Spicka et al. 2011). These methods in evaluating the progress of decomposition are crucial to indicate the extent of tissue degradation hence in estimation of PMI.

\section{AUTOLYSIS AND PUTREFACTION}

Generally, the decomposition process occurs by two mechanisms, which are autolysis and putrefaction (Dent et al. 2004; Janaway et al. 2009a). Autolysis is a cellular self-destruction process caused by hydrolytic enzymes that were originally contained within cells (Enwere 2008; Shirley et al. 2011). Autolysis normally begins at cells, which are metabolically active or contain large amount of water, lysosomes and hydrolytic enzymes. Organs that are involved in high adenosine triphosphate (ATP) production and membrane transportation such as liver and brain are also more susceptible to autolysis reaction as compared to other organs (Gennard 2007; Swann et al. 2010b). At this level, the degradation can only be observed at histological level (Enwere 2008; Janaway et al. 2009a).

Shortly after pulmonary and cardiovascular system stops, supply of oxygen to cell ceases and continued depletion of oxygen concentration will lead to anaerobic condition within the corpse (Swann et al. 2010b; Zhou \& Byard 2011). In order to maintain basic cellular metabolic activity, anaerobic mechanism glycolysis serves as an alternative source of energy and produces waste products such as carbon dioxide and lactate. The cellular $\mathrm{pH}$ drops until the membrane is unable to maintain its normal permeability and rupture accompanied by release of hydrolytic enzymes (Paczkowski \& Schütz 2011; Parkinson et al. 2009). The free hydrolytic enzymes will start to attack any cellular structures which under living condition are not considered as substrate (Powers 2005). Consequently, cellular membrane ruptures and cellular junction breaks down, releasing cellular content (Parsons 2009; Zhou \& Byard 2011). The released cellular content functions as source of nutrient and energy for subsequent microbiological reaction in putrefaction process (Parkinson et al. 2009; Zhou \& Byard 2011).

On the other hand, putrefaction is degradation of tissue by microorganism activity, such as bacteria, fungi and protozoa, which originate from normal biota in human body especially in gastrointestinal tract (Dent et al. 2004; Paczkowski \& Schütz 2011). The process of putrefaction could be accelerated if there are certain ante mortem conditions on the deceased, especially sepsis (either systemic or localized) which will increase the bacteria load in the corpse even prior to invasion of environmental microorganisms (Adams 2009a; Zhou \& Byard 2011). On the other hand, the relative sterility of newborn allow them to deviate from the normal putrefactive process and hence no bloating could be observed in some cases (Mcquinn 2011; Schotsmans et al. 2011b).

Most post mortem changes by putrefaction are visible macroscopically such as discoloration of skin and bloating of body parts. The decompositional product formed by putrefaction may appear in gas, fluid or salt form. Examples of gaseous product include hydrogen sulfide, carbon dioxide, methane, ammonia, sulfur dioxide and hydrogen (Gennard 2007; Vass 2001). Other forms of product include skatole, indole, methylindole, cadaverine, putrescine, various hydrocarbons, nitrogen containing, sulfur containing and phenolic compounds (Dekeirsschieter et al. 2009; Vass et al. 2008). Accumulation of these decompositional (particularly gaseous) products will then lead to swelling at anatomically spacious body parts such as face and abdomen.

\section{EARLY POST MORTEM CHANGES}

Post mortem changes occur in early and late phase. Early post mortem changes include algor mortis, rigor mortis and livor mortis while late post mortem changes involve breakdown of soft tissue leading to noticeable macroscopic changes (Lee 2009; Swift 2006). For corpse that remain in fresh stage, PMI is mostly estimated through examination of algor mortis, livor mortis and rigor mortis (Poloz \& O'day 2009; Tibbett \& Carter 2009).

Algor mortis is the process of decreasing of body temperature to ambient temperature (Parsons 2009; Reddy \& Lowenstein 2011). A corpse loses heat through four mechanisms, which are radiation, convection, conduction and evaporation of any fluid on corpse (Myburgh 2010; Shkrum \& Ramsay 2007). The rate of cooling could be plotted against time after death as a sigmoid curve. Initially, there is a lag phase where body temperature remains stable for a period before the rate of cooling becomes linear and slowly decreases until it reaches equilibrium with ambient temperature (Myburgh 2010; Swift 2006).

Generally, larger difference between body temperature and surrounding temperature will lead to more rapid cooling of temperature (Adams 2009b; Shkrum \& Ramsay 2007). However, the decrease of body temperature may vary depending on the presence or absence of material on the corpse and the environmental conditions where deceased is located. For example, a smaller body size tends to cool faster than a larger one due to its higher total surface area to volume ratio (Lee 2009; Shkrum \& Ramsay 2007). In addition, an obese person can retain body temperature for a much longer time as compared to a slim person due to the difference of body fat content (Smart \& Kaliszan 2012; Wardak \& Cina 2011). Aside from that, there are some ante mortem conditions, which may lead to abnormally high or low body temperature. Condition associated with heat stroke, fever, stress, hyperthyroidism, brain injury, 
malignant hyperthermia, neuroleptic medication, sepsis, presence of toxins or drugs, ante mortem physical activity and age of deceased or certain causes of death (such as suffocation) will lead to abnormal initial body temperature (Adams 2009b; Smart \& Kaliszan 2012).

The common body parts that were used to record temperature would be intrahepatic, rectum and oral temperature in some cases (Lee 2009; Swift 2006). Rectal temperature is normally preferred because it is the easiest and most accessible way to measure core temperature of a body without making extra wounds, unless there is issue of sexual assault or there is no pelvis region left on the corpse (Hubig et al. 2011; Mall et al. 2005; Muggenthaler et al. 2012). However, Den Hartog and Lotens (2004) highlighted some possible sources of error in recording temperature. These errors include type of thermometer used, calibration of thermometer, depth of insertion, a short interval of continuous metabolism rate after death and special circumstances; for example, fire.

Rigor mortis is the phenomenon of muscle stiffness on corpse (Parsons 2009; Swift 2006). Autolysis of sacroplasmic reticulum will release a large amount of calcium ions and allows binding between actin and myosin in muscle tissue. Immediately after death, the remaining ATP in muscle is still sufficient to separate the conjugation between actin and myosin. However these ATP will soon deplete, causing the persistent rigidity of muscle to remain (Powers 2005; Swift 2006).

Rigor mortis involves not only voluntary muscles but also involuntary muscles with one of the most obvious signs being cutis anserine or also known as 'goosebumps' (Powers 2005). It starts from small muscles such as jaw and eye lids, then downwards to neck, trunk and finally to bigger muscle mass on upper limbs and lower limbs (Janaway et al. 2009a; Reddy \& Lowenstein 2011). This is mainly due to the faster ATP loss in smaller muscle mass compared to larger muscle mass. Rigor mortis will remain until enzymatic action degrades these binding sites and the corpse becomes flaccid again. Therefore, inconsistency of rigor mortis on victim with scenario of crime scene may give a hint if there is movement of body prior to the discovery. Surrounding temperature plays an important factor in the formation of rigor mortis. Higher temperature environment will lead to faster formation but shorter duration of rigidity and vice versa for lower temperature setting (Myburgh 2010; Reddy \& Lowenstein 2011).

Rigor mortis is actually different from cadaveric spasm. Cadaveric spasm or cataleptic rigidity is instant contraction of muscle at the moment of death and it is often closely related to the scenario of sudden death or associated with ante mortem state of mind of intense emotion (Janaway et al. 2009a; Reddy \& Lowenstein 2011). This cadaveric spasm seem to exhibit the scenario as if the deceased was frozen at his last action in life, which are related to violent death such as grabbing a weapon or phone or relating to the circumstances of death.

Livor mortis or hypostasis on the other hand could be described as the accumulation or pooling of blood at the lower part of body due to gravity (Lee 2009; Powers 2005). When blood originated from blood vessels, it appears visible on the skin as the colour pink, bluish to dark purplish due to colour of deoxyhemoglobin (Adams 2009b; Myburgh 2010). This development of livor mortis is different from hemorrhage which is due to blood vessels' puncture and may be differentiated from poisoning which also show changes in skin colour, such as carbon monoxide, cyanide, hydrogen sulfide, methemoglobinemia, propane and in some cases of bacterial infection (Reddy \& Lowenstein 2011; Shkrum \& Ramsay 2007).

Before livor mortis is completely fixed, any shifting of body or pressure may change the pattern of the lividity otherwise the colour patch will remain permanently visible on the skin. This criterion is useful in determining any inconsistency between livor mortis and position of the body (Dautartas 2009; Reddy \& Lowenstein 2011). However, there might be several pale areas seen at certain body parts. These are the pressure points where external pressure will prevent the accumulation of blood at that area. The source of pressure could originate from body weight load on area in contact with surface (such as buttocks, midback, calves and heels) or it may be from a mechanically compressed area, tight clothing and belt (Adams 2009b; Reddy \& Lowenstein 2011).

\section{STAGES OF DECOMPOSITION}

Once the corpse enters putrefaction stage, post mortem changes and stage of decomposition provide merely a rough range of PMI due to influence of too many variables (Myburgh 2010; Shattuck 2009). Stages of decomposition are mostly determined by post mortem changes observation or faunal succession pattern analysis (Lee 2009; Myburgh 2010). There are various stages in describing the extent of decomposition, minor variations often present depending on point of view of researchers and geographical differences. There are normally five stages of decomposition process, which are fresh, bloated, active decay, advanced decay and skeletal stage but sometimes bloated stage and active decay are incorporated into one as early decay stage. Observations used to describe the decomposition process are generally applicable everywhere because all corpses decompose with similar pattern of decomposition. However, the rate of decomposition may appear different even within the same district simply due to microclimate, topographical and geographical differences. Local studies found that decomposition process in Malaysia actually progress at a much faster rate compared with other countries in temperate climate (Heo et al. 2007; Teo et al. 2013).

Fresh stage starts immediately at the moment of death. Autolysis cellular destruction occurs in this stage and leads to early post mortem changes, including the aforementioned algor mortis, rigor mortis and livor mortis (Lee 2009; Voss et al. 2008). There is no strong odour of decomposition in fresh stage until the corpse has reached bloated stage (Mcquinn 2011; Shattuck 2009). However soon after death, arthropod activity will start mostly with 
arrival of flies. Previous studies showed that Dipteran is the earliest arthropod that arrives at the corpse (Campobasso et al. 2001; Vitta et al. 2007). Dipteran usually choose natural orifices (eyes, nose, mouth, genital), hair and crevices of corpse as site for oviposition (Ahmad \& Ahmad 2009; Cross \& Simmons 2010).

Bloating is the distension or swelling of body parts due to accumulation of decompositional products (mainly gas) produced by microorganism in anaerobic putrefaction at any anatomically possible spaces in body, included organs and soft tissues. (Dekeirsschieter et al. 2009; Gebhart et al. 2012). Bloating normally starts at abdomen then slowly expands to other body parts, which include genital and face with eye and tongue protrusion (Dekeirsschieter et al. 2009; Gennard 2007). According to Genhart et al. (2012), bloating of corpse is normally noted to be in symmetrical pattern and any violation may indicate hidden injury or temperature variation. The accumulation of decompositional products will continue up to an extent where the corpse will collapse followed by release of the gas, fluid and salt into the surrounding from all possible orifices of corpse (Carter et al. 2007; Enwere 2008).

At the same time, hydrolytic enzymes digest the junction between dermis, causing blister to appear on the skin and in some cases the stratum corneum to detach (Lee 2009; Shkrum \& Ramsay 2007). Skin slippage at hand and feet is common and often known as 'degloving' phenomenon (Powers 2005; Shkrum \& Ramsay 2007). Bloating is often noticed together with marbling when arteries and veins are visible on skin appearance due to formation of sulf-hemoglobin from bacterial reaction in blood vessels (Powers 2005; Shkrum \& Ramsay 2007). The changes may gradually shift into larger discoloration of skin with range of discoloration varying from green, brown and grey to black in colour (Parsons 2009; Shattuck 2009).

When post bloating of the corpse occurs, decomposition process proceeds into active decay stage. The rate of degradation turns faster because rupture of skin integration opens extra access points for microorganisms, arthropods and scavengers. The ruptured skin of corpse may turn black accompanied by hair loss (Shkrum \& Ramsay 2007). Liquefaction of soft tissues starts with the presence of froth while extremities of corpse may desiccate in some cases (Parsons 2009; Sharanowski et al. 2008). At this level, the activity of Dipteran larvae is at maximum with fast consumption of soft tissue and some species of Coleoptera may be present (Carter et al. 2007; Matuszewski et al. 2008).

The decomposition process is then followed by advanced decay stage, which is also known as black putrefaction or late decaying stage. Bone exposure starts and the overall corpse shows caving in appearance with some higher degradation-resistant tissues left behind such as cartilage, hair and desiccated tissue (Dekeirsschieter et al. 2009; Sharanowski et al. 2008). There is only weak odour of decaying smell or cheesy odour in this stage
(Ahmad \& Ahmad 2009; Sharanowski et al. 2008). One of the major indicators for this stage is major migration of Dipteran larvae for pupation (Matuszewski et al. 2008; Sharanowski et al. 2008). Population of Dipteran species is gradually replaced by Coleoptera species as part of the faunal succession pattern (Ahmad et al. 2011; Voss et al. 2008, 2011).

Dry remains or skeletal stage is reached when there is a very high degree of bone exposure but extreme breakdown of the bone material has not started (Sharanowski et al. 2008; Swann et al. 2010b). Adlam and Simmons (2007) defined skeletonization in their studies as any one of: only spine was left underneath dried skin accompanied by major loss of intra-abdominal tissue; higher than $50 \%$ of bone exposure with minimal moisture; or more than $30 \%$ of bones already underwent bleaching and weathering process (Adlam \& Simmons 2007). During this stage, only a very few amount of dried skin, tendon and cartilage will present. Minimal moisture from environment or grease may present on the bone surface and the smell of decomposition generally fades off (Matuszewski et al. 2008). Some insect species are still present in this stage but mostly from Coleoptera and Acari (mites) (Ahmad et al. 2011; Braig \& Perotti 2009). Sequence of skeletonization may vary depending on environmental setting and condition of the corpse. It is believed that under normal circumstances, head, face and limbs will decompose faster than the corpse but this sequence is subject to any variation caused by position of corpse and environmental setting (Bachmann \& Simmons 2010; Dautartas 2009).

When the corpse reached the skeletal stage, decomposition slows down dramatically and progress at timeframe of years or decades. The bones will undergo process of microbial attack of collagen; weathering, bleaching, exfoliation, cracking of cortical bone (followed by exposure of trebacular bone), loss of its inorganic mineral content and invasion of vegetation root (Shattuck 2009; Vass 2001). PMI at this stage may be difficult to determine although there are methods to examine skeletal remains based on completeness, fragmentation and articulation or weathering effect (Lieverse et al. 2006; Ross \& Cunningham 2011). Ross and Cunningham (2011) estimated that complete decomposition of bones require time between six to thirty years in a tropical environment setting.

In real forensic context, different body parts of a corpse decompose at different speed thus different stages of decomposition could be observed on the same corpse simultaneously. It could be challenging for forensic pathologists to use a single stage of decomposition to describe the extent of degradation of a corpse (Adlam \& Simmons 2007; Duday \& Guillon 2006). It is generally accepted that head and limbs will decompose faster compared to body trunk, mainly because there is a higher concentration of soft tissue to be digested (Braig \& Perotti 2009; Matuszewski et al. 2008). 


\section{MUMMIFICATION}

Mummification is a process of desiccation that occurs at tissue of corpse, mostly induced by dry environment or air current, high temperature or situation that is low in humidity (Gennard 2007; Schotsmans et al. 2011b). It originates from the Persian word 'múmiya' which means bitumen (Schotsmans et al. 2011b). In mummification, the most significant observation is the skin will turn into dark brown with hard, leathery and parchment-like appearance (Janaway et al. 2009b; Schotsmans et al. 2011b). Dehydration of body tissues allows the preservation of the corpse for a longer period (Carter et al. 2007; Janaway et al. $2009 b$ ). This is mainly because the moisture content is not adequate for microorganism activity of tissue degradation, causing decomposition to be hindered (Janaway et al. 2009b; Powers 2005). The corpse loses its moisture content and tissue mass volume, leaving behind skin that then further shrinks into smaller volume. In some cases, the extreme shrinkage at joints will tear the skin apart especially at groin, neck and armpit area.

A thin corpse is more susceptible to mummification as compared to an obese due to difference in muscle bulk and adipose tissue (Reddy \& Lowenstein 2011; Schotsmans et al. 2011b). Newborn babies also tend to mummify as they are relatively sterile in their gastrointestinal tracts and thus there is no microorganism population to kick start the putrefaction internally (Janaway et al. 2009b; Schotsmans et al. 2011b). Also, the presence of good air flow and any covering or clothing made of material that facilitate evaporation of fluids from body may indirectly enhance formation of a mummified corpse (Janaway et al. 2009a; Teo et al. 2013).

Mummification of a corpse could occur as whole body mummification or at localized body parts such as fingers, tongue and toes (Forbes et al. 2005; Janaway et al. 2009b). Mummification may occur on internal organs as well although they are often to be the last part observed to mummify (Mcquinn 2011; Schotsmans et al. 2011b). When the skin of a corpse mummify, the preservation of internal organs depends on the extent of putrefaction and autolysis when the environmental setting favours mummification (Janaway et al. 2009a). Therefore, the internal organs may appear moist while the skin is already mummified (Janaway et al. 2009b; Parsons 2009). Generally, it is also accepted that burial with soil of coarse properties (such as sand) allow dehydration of tissues thus enhancing mummification (Carter et al. 2007; Gaudry 2010). Schotsmans et al. (2011a) also concluded that burial with the presence of quicklime will induce mummification of corpse at skin level, but not including the internal organs.

\section{ADIPOCERE}

Adipocere is a consistent, greasy, wax-like appearance of substance with the colour ranging from yellowish white to gray in colour (Notter et al. 2009; Ubelaker \& Zarenko 2011). It can preserve soft tissue, internal organs or the whole corpse by inhibiting bacterial reaction, arthropod and animal scavenging activity (Fiedler et al. 2004; Forbes et al. 2005). For example, preservation of hyoid bone fracture and toxicology evidence preserved in internal organs can help in determining accurate cause of death for deceased (Ubelaker \& Zarenko 2011). Adipocere actually originates from Latin words, 'adipo' or 'adeps' meaning fat and 'cera' or 'cere' meaning wax (Ubelaker \& Zarenko 2011; Widya et al. 2012). The formation of adipocere also known as saponification, is another form of variation of post mortem changes that can preserve the corpse for a significant period of time (Durães et al. 2010; Fiedler et al. 2004). However, the formation of adipocere will adversely affect identification of deceased and PMI estimation (Pinheiro \& Cunha 2006; Widya et al. 2012). The species of bacteria involve in the formation of adipocere include Clostridium perfringens and Clostridium frigidicanes (Vass 2001; Widya et al. 2012). Previous studies showed that formation of adipocere require moist and anaerobic condition (Ubelaker \& Zarenko 2011; Widya et al.2012). However, several previous studies documented that adipocere can also be found on corpses discovered from sea bed (Anderson 2010; Ubelaker \& Zarenko 2011).

Previous studies proved that formation of adipocere normally starts from adipose tissue in the body (Forbes et al.2005; Wilson et al.2007). Obese individual, female, the elderly and babies have higher tendency to form adipocere as compared to thin individual, male and adult due to the variation of fat property and composition (Fiedler \& Graw 2003; Schotsmans et al.2011b). Hydrolysis of triglyceride by bacterial action yields a mixture of free fatty acids and the unsaturated fatty acids will transform into saturated fatty acids via oxidation, hydration or hydrogenation (Fiedler et al. 2004; Notter et al. 2009). The types saturated fatty acid mainly consist of palmitic, stearic and myristic acid (Durães et al. 2010; Notter et al. 2009). The fatty acids will then interact with inorganic ions and form salts.

There are some controversy among scientists about the difference between soft paste-like adipocere and hardened brittle armour-like adipocere. Powers (2005) mentioned that the soft paste adipocere is made of conjugation with sodium ion and the latter one mainly with potassium ion. However, Fiedler et al. (2004) and Vass (2001) stated the opposite way with addition of magnesium ion and calcium ion in producing brittle adipocere other than sodium ion. Some researchers believe that the soft paste adipocere will eventually harden with time (Notter et al. 2009; Wilson et al.2007). This makes sense since there might be exchange of ions in salts meanwhile evaporation of fluids along times.

It is generally believed that formation of adipocere is related to burial with soil of fine texture property, loam enriched, low in permeability and poor drainage property (Durães et al. 2010). High clay, silt and lime content that increase alkaline value of soil will further enhance the formation of adipocere (Fiedler \& Graw 2003; Schotsmans et al. 2011a). This is because these soil properties entrap the fluid released during decomposition around the corpse, which is essential for transformation of adipose tissue into 
adipocere. Some studies proved that moisture content inside body itself is already sufficient for formation of adipocere (Carter et al. 2007). It is also believed that the formation of adipocere is normally associated with clothing and/or covering (Fiedler et al. 2012; Forbes et al. 2005). However, the variety of fabric used and their properties are too wide, causing their roles in enhancing or inhibiting formation of adipocere to remain unclear. Researches by Dautartas (2009) and Shirley et al. (2011) mentioned that the presence of plastic wrapping will enhance formation of adipocere. Meanwhile, Forbes et al. (2005) found that the impermeable property of plastic may cause accumulation of waste product and inhibition of free saturated fatty acids from interacting with soil to transform into adipocere.

Although the adipocere formed will retard the decomposition process, adipocere itself is also subject to decomposition once it is exposed to aerobic condition (Fiedler et al. 2012; Wilson et al. 2007). Population involved in decomposition of adipocere is mainly Grampositive bacteria such as Bacillius sp., Cellulomonas sp. and Nocardia sp. (Fiedler \& Graw 2003; Fiedler et al. 2004).

\section{BURIED CORPSE}

Undoubtedly, a corpse will always be the most important evidence in homicide case and criminals often choose to conceal the corpse from law enforcement. Burial is one of the methods that can be used to hide the corpse from public attention (Enwere 2008; Prangnell \& Mcgowan 2009). This type of shallow clandestine grave often ranges from 0.3 to $0.7 \mathrm{~m}$ depth compared to legal graveyard with graves at 1.2 to $1.4 \mathrm{~m}$ depth (Hoffman et al. 2009; Prangnell \& Mcgowan 2009). The site chosen for clandestine graves commonly follows these criteria such as geographically located at an area of short distance away from rarely used pathways or roads, roughly ten feet next to the nearest large tree, surrounded by bushes, shrubs or leafage with the corpse clothed (or wrapped) (Hoffman et al. 2009).

It is generally accepted that corpses buried underground decompose slower compared to corpses left on ground surface (Campobasso et al. 2001; Teo et al. 2013). According to Casper's rule, a buried corpse requires eight times longer than a corpse decaying on ground surface to reach the same stage of decomposition (Fiedler \& Graw 2003; Gennard 2007). Depth of grave plays an essential role in determining to what extent the slowing down of decomposition will be. Research done by Rodriguez is one of the earliest of its kind in taphonomy field and he found that corpses buried at 0.3 to $0.6 \mathrm{~m}$ depth takes several months up to a year to reach dry remains stage while 0.9 to $1.2 \mathrm{~m}$ depth require years before the corpse is fully skeletonized (Gaudry 2010; Shattuck 2009).

The main reason for the slower rate of decomposition is due to the restricted access for majority of insect and scavenger animals at buried corpse (Campobasso et al. 2001; Ross \& Cunningham 2011). However, buried corpse actually has its own faunal succession pattern, which is different from that on a ground surface corpse. Some species of Dipteran are able to move through the soil layer to reach the corpse or they lay eggs on the ground surface and the hatched larvae then moves down onto the corpse through rain infusion; such as Muscidae, Phoridae and Callophoridae (in some cases) (Gaudry 2010; Myburgh 2010). Common entomological evidences that could be collected from buried corpse can be categorized into Arachnida (such as Acari, Diplopoda and Araneae) and also Insecta (which include Diptera, Coleoptera, Dermaptera, Collembola, Thysanura, Blattodea and Hymeonoptera) (Gaudry 2010; Gennard 2007).

Preburial exposure of corpse towards arthropod activity may enhance decomposition process compared with those without exposure by attracting the early waves of decomposer arthropods. However, even if there is preburial exposure to arthropod activity, there is lack of subsequent wave of insect from normal faunal succession and there will not be a real larvae mass on buried corpses (Bachmann \& Simmons 2010; Dautartas 2009). Therefore, decomposition in graves mainly relies on microbiological activity, with population from both gastrointestinal tract and surrounding soil (Carter \& Tibbett 2008; Wilson et al. 2007).

Lower temperature in grave as compared to ambient temperature is another reason for slower decomposition of a buried corpse. The soil layer above the grave functions as an insulator and block the heat energy from solar radiation (Myburgh 2010; Prangnell \& Mcgowan 2009). Combined with the soil thermal heat storage capacity on its own, the temperature in grave fluctuates in a smaller magnitude compared to ground surface (Prangnell \& Mcgowan 2009). However, the temperature inside the grave is still adequate for microbial metabolism. With the increase of depth, temperature will be lower and thus slower the degradation of tissue (Bachmann \& Simmons 2010; Schultz 2008). The low oxygen content underground also restricts the microbial population to only anaerobic strands thus also delaying the decomposition process (Dent et al. 2004; Statheropoulos et al. 2011).

A corpse decays faster when in contact with soil and hence every material that separate corpse from soil will delay rate of decomposition (Duday \& Guillon 2006). Examples of these include clothing, grave and bedding material. Coffin made of pine and spruce will enhance degradation of corpse while oak, lead and zinc coffin will retard the decomposition process (Fiedler \& Graw 2003). Müller et al. (2011) also found that coffin that contain high amount of heavy metal can preserve the buried corpse by inhibiting microbial metabolism. However, commercial coffin nowadays actually enhance decomposition because its absorbent property facilitates dissolution of soft tissue and prevent formation of adipocere (Dautartas 2009; Gaudry 2010). Meanwhile, air void in coffin allows a small extent of aerobic condition that supports aerobic microbial population or survival of some arthropods if there was preburial exposure (Dautartas 2009; Janaway et al. 2009b). 
Air tight coffin on the other hand will inhibit the dispersion of decompositional products which then turn into toxic thus delaying decomposition (Ross \& Cunningham 2011).

When the corpse buried in grave has reached dry remains stage, the position of bone may change due to decay of tissue and force of gravity if there is free space around the corpse (Duday \& Guillon 2006). The PMI may be even harder to be determined when the corpse has reached skeletonization stage. Study done by Jaggers and Rogers (2009) found that there is no change in colour, texture or even overall condition of pig bones after five months of post burial period.

In buried cases, the presence of wounds or penetrative trauma seem to be not as significant as compared with corpses that decompose on ground surface because there is less chances of arthropod oviposition on the wounds (Bachmann \& Simmons 2010; Cross \& Simmons 2010). At the same time, repeated burial in the same grave will accelerate the rate of decomposition due to the ready presence of rich microbiology population which is optimum in decaying organic matter (Carter \& Tibbett 2008; Pringle et al. 2010). However, study done by Fiedler and Graw (2003) found that humus produced by previously buried corpse may cause the surrounding soil spores in grave to become smaller and cause higher fluid retention for the subsequent buried corpse hence delaying the decomposition process. This phenomenon is the same for corpses buried directly in soil with high amount of clay, which has a higher fluid retention property. The experiment done by Schultz (2008) and Schultz et al. (2006) used buried pig carcass at soil with high composition of clay showed signs of soft tissue preservation after one year regardless of the size of pig used.

Several previous studies linked released chemical compound or odour analysis to PMI estimation (Paczkowski \& Schütz 2011; Swann et al. 2010a). Review done by Swann et al. (2010b) explained analytical instruments used in analyzing various decompositional products and the benefits in understanding the process of decomposition. Vass et al. (2004) studied the volatile decompositional products that could be detected on ground surface for various depths of burial. There are eight major classes of products, which include cyclic and non-cyclic hydrocarbon, nitrogen compound, sulfur compound, oxygen compound, halogen compound, acid and ester compound. Another similar research further identified the key volatile compounds which are related to either soft tissue degradation or breakdown of bone component (Vass et al. 2008). Nitrogen-reactive ninhydrin and fatty acids in gravesoil as product from degradation of fat and protein could also be analyzed to provide a certain range of PMI or in locating a grave (Swann et al. 2010a; Tibbett \& Carter 2009).

Research done by Vass et al. (2004) showed the first volatile compound was detected on ground surface at 17 days for a 1.5 feet depth grave, while a 2.5 feet grave needs two months and above for the first volatile decompositional product to be detected. Factors that affecting release of decompositional product include temperature, moisture, soil $\mathrm{pH}$ value and the availability of oxygen in burial (Vass et al. 2008). Dalva et al. (2012) also stated that for deep burial, the chemical product released from decomposition might be utilized by neighboring microbiology population as substrate and hence not detected. In other words, the compound detected on ground surface for deep graves may not have originate from the decaying corpse but is a product from metabolism of other soil population that is not related to degradation process as predicted by Vass et al. (2004).

\section{CONCLUSION}

Decomposition is a sophisticated process representing how a corpse slowly degrades into brick components and is gradually recycled into the environment by decomposer activities, such as microorganisms, invertebrates and vertebrate fauna. The degradation process from a fresh cadaver to dry skeletal remains until the destruction of bone element takes time from years if not centuries, if variations such as mummification and adipocere occur. However, the decomposition process itself is subject to various intrinsic such as age, weight, ante mortem condition, presence of trauma, drugs or toxin and extrinsic factors such as environment setting, temperature, moisture level, sun exposure, layers and type of clothing, coffin and bedding and accessibility of insect. In fact, the condition of corpses in real crime scene is often diverse and numerous variables may have taken part in leading to the point of decomposition process before the arrival of experts. Therefore, it is difficult to compare between studies and real cases due to differences in climate, geographical location, subject or model used and setting of the study. Analysis for case reports should not rely solely on single taphonomic research, which mostly focuses on a few variables at one time. Nevertheless, estimation of PMI plays a very important role not only in the investigation of suspect and manner of death, but also assists the jurisdictional system in making the right decision. At the end of the day, there is no single estimation method that can provide a precise moment of PMI above all but in range of hours until years, thus combination between different approaches of estimation is necessary to increase the accuracy of PMI. Although there are extensive forensic taphonomic studies conducted to study how different variables affecting decomposition process, the correlation between different factors is yet to be uncovered in detail.

\section{REFERENCES}

Adams, V.I. 2009a. Legal aspects of autopsy practice. In Handbook of Autopsy Practice, edited by Waters, B.L. Totowa: Humana Press Inc. pp. 137-143.

Adams, V.I. 2009b. Medicolegal autopsy and postmortem toxicology. In Handbook of Autopsy Practice, edited by Waters, B.L. Totowa: Humana Press Inc. pp. 125-136. 
Adlam, R.E. \& Simmons, T. 2007. The effect of repeated physical disturbance on soft tissue decomposition-are taphonomic studies an accurate reflection of decomposition? Journal of Forensic Sciences 52(5): 1007-1014.

Ahmad, A. \& Ahmad, A.H. 2009. A preliminary study on the decomposition and dipteran associated with exposed carcasses in an oil palm plantation in Bandar Baharu, Kedah, Malaysia. Tropical Biomedicine 26(1): 1-10.

Ahmad, N.W., Lim, L.H., Dhang, C.C., Heo, C.C., Ag, A., Wan, W.N., Mustaffa, C.W.K., Jeffery, J., Hashim, R. \& Azirun, S.M. 2011. Comparative insect fauna succession on indoor and outdoor monkey carrions in a semi-forested area in Malaysia. Asian Pacific Journal of Tropical Biomedicine 1(2): S232-S238.

Anderson, G.S. 2010. Decomposition and invertebrate colonization of cadavers in coastal marine environments. In Current Concepts in Forensic Entomology, edited by Amendt, J., Lee, G.M., Campobasso, C.P. \& Grassberger, M. New York: Spinger Press. pp. 223-272.

Bachmann, J. \& Simmons, T. 2010. The influence of preburial insect access on the decomposition rate. Journal of Forensic Sciences 55(4): 893-900.

Braig, H.R. \& Perotti, M.A. 2009. Carcases and mites. Experimental and Applied Acarology 49(1): 45-84.

Campobasso, C.P., Di Vella, G. \& Introna, F. 2001. Factors affecting decomposition and diptera Colonization. Forensic Science International 120(1-2): 18-27.

Carter, D.O. \& Tibbett, M. 2008. Does repeated burial of skeletal muscle tissue (Ovis aries) in soil affect subsequent decomposition? Applied Soil Ecology 40(3): 529-535.

Carter, D.O., Yellowlees, D. \& Tibbett, M. 2007. Cadaver decomposition in terrestrial ecosystems. Naturwissenschaften 94(1): 12-24.

Carter, D.O., Yellowlees, D. \& Tibbett, M. 2008. Temperature affects microbial decomposition of cadavers (Rattus rattus) in contrasting soils. Applied Soil Ecology 40(1): 129-137.

Carter, D.O., Yellowlees, D. \& Tibbett, M. 2008. Using ninhydrin to detect gravesoil. Journal of Forensic Sciences 53(2): 397-400.

Cross, P. \& Simmons, T. 2010. The influence of penetrative trauma on the rate of decomposition. Journal of Forensic Sciences 55(2): 295-301.

Dalva, M., Kalácska, M., Moore, T.R. \& Costopoulos, A. 2012. Detecting graves with methane. Geoderma 189: 18-27.

Dautartas, A.M. 2009. The effect of various coverings on the rate of human decomposition. Thesis. University of Tennessee, Knoxville (unpublished).

Dekeirsschieter, J., Verheggen, F., Gohy, M., Hubrecht, F., Bourguignon, L., Lognay, G. \& Haubruge, E. 2009. Cadaveric volatile organic compounds released by decaying pig carcasses (Sus domesticus L.) in different biotopes. Forensic Science International 189(1): 46-53.

Den Hartog, E.A. \& Lotens, W.A. 2004. Postmortem time estimation using body temperature and a finite-element computer model. European Journal of Applied Physiology 92(6): 734-737.

Dent, B., Forbes, S. \& Stuart, B. 2004. Review of human decomposition processes in soil. Environmental Geology 45(4): 576-585.

Duday, H. \& Guillon, M. 2006. Understanding the circumstances of decomposition when the body is skeletonized. In Forensic Anthropology and Medicine: Complimentary Sciences from Recovery to Cause of Death, edited by Schmitt, A., Cunha, E. \& Pinheiro, J. Totowa: Humana Press Inc. pp. 117-157.
Durães, N., Cortez, D., Algarra, M., Sánchez, F.G., RodríguezBorges, J.E., Bobos, I. \& Esteves Da Silva, J.C.G. 2010. Comparison of adipocere formation in four soil types of the Porto (Portugal) District. Forensic Science International 195(1): e161-e168.

Enwere, P.I. 2008. Taphonomy of child-sized remains in shallow grave and surface deposit scenarios. Thesis and DissertationsAnthropology, Texas State University (unpublished).

Fenoglio, S., Bo, T., Cammarata, M., Malacarne, G. \& Del Frate, G. 2010. Contribution of macro-and micro-consumers to the decomposition of fish carcasses in low-order streams: An experimental study. Hydrobiologia 637(1): 219-228.

Fiedler, S. \& Graw, M. 2003. Decomposition of buried corpses, with special reference to the formation of adipocere. Naturwissenschaften 90(7): 291-300.

Fiedler, S., Breuer, J., Pusch, C., Holley, S., Wahl, J., Ingwersen, J. \& Graw, M. 2012. Graveyards - special landfills. Science of the Total Environment 419: 90-97.

Fiedler,S.,Schneckenberger,K.\& Graw,M. 2004.Characterization of soils containing adipocere. Archives of Environmental Contamination and Toxicology 47(4): 561-568.

Forbes, S.L., Stuart, B.H. \& Dent, B.B. 2005. The effect of the method of burial on adipocere formation. Forensic Science International 154(1): 44-52.

Gaudry, E. 2010. The insects colonisation of buried remains. In Current Concepts in Forensic Entomology, edited by Amendt, J., Campobasso, C.P., Goff, M.L. \& Grassberger, M. New York: Springer Press. pp. 273-311.

Gebhart,F.T.F., Brogdon, B.,Zech,W.D., Thali, M.J. \& Germerott, T. 2012. Gas at postmortem computed tomography-an evaluation of 73 non-putrefied trauma and non-trauma cases. Forensic Science International 222(1): 162-169.

Gennard, D.E. 2007. Forensic Entomology: An Introduction. West Sussex: John Wiley \& Sons Ltd.

Heo, C.C., Marwi, M.A., Salleh, A.F.M., Jeffery, J. \& Omar, B. 2007. A preliminary study of insect succession on a pig carcass in a palm oil plantation in Malaysia. Tropical Biomedicine 24(2): 23-27.

Hoffman, E.M., Curran, A.M., Dulgerian, N., Stockham, R.A. \& Eckenrode, B.A. 2009. Characterization of the volatile organic compounds present in the headspace of decomposing human remains. Forensic Science International 186(1): 6-13.

Hubig, M., Muggenthaler, H. \& Mall, G. 2011. Influence of measurement errors on temperature-based death time determination. International Journal of Legal Medicine 125(4): 503-517.

Jaggers, K.A. \& Rogers, T.L. 2009. The effects of soil environment on postmortem interval: a macroscopic analysis. Journal of Forensic Sciences 54(6): 1217-1222.

Janaway, R.C., Percival, S.L. \& Wilson, A.S. 2009a. Decomposition of human remains. In Microbiology and Aging, edited by Percival, S.L. New York: The Humana Press. pp. 313-334.

Janaway, R.C., Wilson, A.S., Díaz, G.C. \& Guillen, S. 2009b. Taphonomic changes to the buried body in arid environments: An experimental case study in Peru. In Criminal and Environmental Soil Forensics, edited by Ritz, K., Dawson, L. \& Miller, D. Bradford: Springer Science \& Business Media. pp. 341-356.

Kaliszan, M., Hauser, R. \& Kernbach-Wighton, G. 2009. Estimation of the time of death based on the assessment of post mortem processes with emphasis on body cooling. Legal Medicine 11(3): 111-117. 
Lee, G.M. 2009. Early post-mortem changes and stages of decomposition in exposed cadavers. Experimental and Applied Acarology 49(1): 21-36.

Lieverse, A.R., Weber, A.W. \& Goriunova, O.I. 2006. Human taphonomy at Khuzhir-Nuge Xiv, Siberia: A new method for documenting skeletal condition. Journal of Archaeological Science 33(8): 1141-1151.

Madea, B. 2005. Is there recent progress in the estimation of the postmortem interval by means of thanatochemistry? Forensic Science International 151(2-3): 139-150.

Mall, G., Eckl, M., Sinicina, I., Peschel, O. \& Hubig, M. 2005. Temperature-based death time estimation with only partially known environmental conditions. International Journal of Legal Medicine 119(4): 185-194.

Matuszewski, S., Bajerlein, D., Konwerski, S. \& Szpila, K. 2008. An initial study of insect succession and carrion decomposition in various forest habitats of central Europe. Forensic Science International 180(2-3): 61-69.

Mcquinn, B.C. 2011. Impact of embalming and burial on decomposition rates and diffusion of volatile fatty acids in Kentucky. Thesis, Eastern Kentucky University (unpublished).

Muggenthaler, H., Sinicina, I., Hubig, M. \& Mall, G. 2012. Database of post-mortem rectal cooling cases under strictly controlled conditions: A useful tool in death time estimation. International Journal of Legal Medicine 126(1): 79-87.

Müller, K., Chadefaux, C., Thomas, N. \& Reiche, I. 2011. Microbial attack of archaeological bones versus high concentrations of heavy metals in the burial environment: A case study of animal bones from a mediaeval copper workshop in Paris. Palaeogeography, Palaeoclimatology, Palaeoecology 310(1): 39-51.

Myburgh, J. 2010. Estimating the post-mortem interval using accumulated degree-days in a South African setting. Thesis, University of Pretoria (unpublished).

Notter, S.J., Stuart, B.H., Rowe, R. \& Langlois, N. 2009. The initial changes of fat deposits during the decomposition of human and pig remains. Journal of Forensic Sciences 54(1): 195-201.

Paczkowski, S. \& Schütz, S. 2011. Post-mortem volatiles of vertebrate tissue. Applied Microbiology and Biotechnology 91(4): 917-935.

Parkinson, R.A., Dias, K.R., Horswell, J., Greenwood, P., Banning, N., Tibbett, M. \& Vass, A.A. 2009. Microbial community analysis of human decomposition on soil. Dlm. Criminal and Environmental Soil Forensics, edited by Ritz, K., Dawson, L. \& Miller, D. Bradford: Springer Science \& Business Media. pp. 379-394.

Parsons, H.R. 2009. The postmortem interval: A systematic study of pig decomposition in west Central Montana. Thesis, Montana State University (unpublished).

Pinheiro, J. \& Cunha, E. 2006. Forensic investigation of corpses in various states of decomposition. In Forensic Anthropology and Medicine: Complimentary Sciences from Recovery to Cause of Death, edited by Schmitt, A., Cunha, E. \& Pinheiro, J. Totowa: Humana Press Inc. pp. 159-195.

Poloz, Y.O. \& O'day, D.H. 2009. Determining time of death: Temperature-dependent postmortem changes in calcineurin A, MARCKS, CaMKII and protein phosphatase 2A in Mouse. International Journal of Legal Medicine 123(4): 305-314.

Powers, R.H. 2005. The decomposition of human remains. In Forensic Medicine of the Lower Extremity, edited by Rich, J., Dean, D.E. \& Powers, R.H. Totowa: The Humana Press. pp. 3-15.
Prangnell, J. \& Mcgowan, G. 2009. Soil temperature calculation for burial site analysis. Forensic Science International 191(13): 104-109.

Pringle, J.K., Cassella, J.P. \& Jervis, J.R. 2010. Preliminary soilwater conductivity analysis to date clandestine burials of homicide victims. Forensic Science International 198(1): 126-133.

Reddy, K. \& Lowenstein, E.J. 2011. Forensics in Dermatology: Part I. Journal of the American Academy of Dermatology 64(5): 801-808.

Ross, A.H. \& Cunningham, S.L. 2011. Time-since-death and bone weathering in a tropical environment. Forensic Science International 204(1): 126-133.

Schotsmans, E.M.J., Denton, J., Dekeirsschieter, J., Ivaneanu, T., Leentjes, S., Janaway, R.C. \& Wilson, A.S. 2011a. Effects of hydrated lime and quicklime on the decay of buried human remains using pig cadavers as human body analogues. Forensic Science International 207(1): 51-59.

Schotsmans, E.M.J., Van De Voorde, W., De Winne, J. \& Wilson, A.S. 2011b. The impact of shallow burial on differential decomposition to the body: A temperate case study. Forensic Science International 206(1): e43-e48.

Schultz, J.J. 2008. Sequential monitoring of burials containing small pig cadavers using ground penetrating radar. Journal of Forensic Sciences 53(2): 279-287.

Schultz, J.J., Collins, M.E. \& Falsetti, A.B. 2006. Sequential monitoring of burials containing large pig cadavers using ground penetrating radar. Journal of Forensic Sciences 51(3): 607-616.

Sharanowski, B.J., Walker, E.G. \& Anderson, G.S. 2008. Insect succession and decomposition patterns on shaded and sunlit carrion in Saskatchewan in three different seasons. Forensic Science International 179(2-3): 219-240.

Shattuck, C.M. 2009. An analysis of decomposition rates on outdoor surface variations in Central Texas. Thesis and Dissertions-Anthropology, Texas State University (unpublished).

Shirley, N.R., Wilson, R.J. \& Jantz,L.M. 2011. Cadaver use at the University of Tennessee's Anthropological Research Facility. Clinical Anatomy 24(3): 372-380.

Shkrum, M.J. \& Ramsay, D.A. 2007. Postmortem Changes. In Forensic Pathology of Trauma: Common Problems for the Pathologist, edited by Shkrum, M.J. \& Ramsay, D.A. Totowa: Humana Press Inc. pp. 23-56.

Smart, J.L. \& Kaliszan, M. 2012. The post mortem temperature plateau and its role in the estimation of time of death: A review. Legal Medicine 14(2): 55-62.

Spicka, A., Johnson, R., Bushing, J., Higley, L.G. \& Carter, D.O. 2011. Carcass mass can influence rate of decomposition and release of ninhydrin-reactive nitrogen into gravesoil. Forensic Science International 209(1): 80-85.

Statheropoulos, M., Agapiou, A., Zorba, E., Mikedi, K., Karma, S., Pallis, G., Eliopoulos, C. \& Spiliopoulou, C. 2011. Combined chemical and optical methods for monitoring the early decay stages of surrogate human models. Forensic Science International 210(1): 154-163.

Swann, L., Chidlow, G.E., Forbes, S. \& Lewis, S.W. 2010a. Preliminary studies into the characterization of chemical markers of decomposition for geoforensics. Journal of Forensic Sciences 55(2): 308-314.

Swann, L., Forbes, S. \& Lewis, S. 2010b. Analytical separations of mammalian decomposition products for forensic science: A review. Analytica Chimica Acta 682: 9-22. 
Swift, B. 2006. The timing of death. Essentials of Autopsy Practice: Current Methods and Modern Trends, edited by Rutty, G.N. New York: Springer. pp.189-214.

Teo, C.H., Hamzah, S.P.A., Khairul, O., Atiah, A.A.G. \& Hamzah, N.H. 2013. Post mortem changes in relation to different types of clothing. Malaysian Journal of Pathology 35(1): 77-85.

Tibbett, M. \& Carter, D.O. 2009. Research in forensic taphonomy: A soil-based perspective. In Criminal and Environmental Soil Forensics, edited by Ritz, K., Dawson, L. \& Miller, D. Bradford: Springer Science \& Business Media. pp. 317-331.

Ubelaker, D.H. \& Zarenko, K.M. 2011. Adipocere: What is known after over two centuries of research. Forensic Science International 208(1): 167-172.

Vass, A.A. 2001. Beyond the grave-understanding human decomposition. Microbiology Today 28(1): 190-193.

Vass, A.A., Smith, R.R., Thompson, C.V., Burnett, M.N., Dulgerian, N. \& Eckenrode, B.A. 2008. Odor analysis of decomposing buried human remains. Journal of Forensic Sciences 53(2): 384-391.

Vass, A.A., Smith, R.R., Thompson, C.V., Burnett, M.N., Wolf, D.A., Synstelien, J.A., Dulgerian, N. \& Eckenrode, B.A. 2004. Decompositional odor analysis database. Journal of Forensic Sciences 49(4): 760-769.

Vitta, A., Pumidonming, W., Tangchaisuriya, U., Poodendean, C. \& Nateeworanart, S. 2007. A preliminary study on insects associated with pig (Sus scrofa) carcasses in Phitsanulok, Northern Thailand. Tropical Biomedicine 24(2): 1-5.

Voss, S.C., Cook, D.F. \& Dadour, I.R. 2011. Decomposition and insect succession of clothed and unclothed carcasses in Western Australia. Forensic Science International 211(1-3): 67-75.
Voss, S.C., Forbes, S.L. \& Dadour,I.R. 2008. Decomposition and insect succession on cadavers inside a vehicle environment. Forensic Science, Medicine, and Pathology 4(1): 22-32.

Wardak, K.S. \& Cina, S.J. 2011. Algor mortis: An erroneous measurement following postmortem refrigeration. Journal of Forensic Sciences 56(5): 1219-1221.

Widya, M., Moffatt, C. \& Simmons, T. 2012. The formation of early stage adipocere in submerged remains: A preliminary experimental study. Journal of Forensic Sciences 57(2): 328-333.

Wilson, A.S., Janaway, R.C., Holland, A.D., Dodson, H.I., Baran, E., Pollard, A.M. \& Tobin, D.J. 2007. Modelling the buried human body environment in upland climes using three contrasting field sites. Forensic Science International 169(1): 6-18.

Zhou, C. \& Byard, R.W. 2011. Factors and processes causing accelerated decomposition in human cadavers-An overview. Journal of Forensic and Legal Medicine 18(1): 6-9.

School of Diagnostic \& Applied Health Sciences

Faculty of Health Sciences

Universiti Kebangsaan Malaysia

43600 Bangi, Selangor

Malaysia

*Corresponding author; email: drsripaah@gmail.com

Received: 19 January 2014

Accepted: 25 April 2014 